\title{
TWO NEW STERILE SPECIES OF LOXOSPORA (SARRAMEANACEAE: LICHENIZED ASCOMYCETES) FROM THE MID-ATLANTIC COASTAL PLAIN
}

\author{
JAMES C. LENDEMER \\ Institute of Systematic Botany \\ The New York Botanical Garden \\ Bronx, NY 10458-5126, U.S.A.
}

\begin{abstract}
Molecular phylogenetic analyses of mtSSU and nrITS sequence data show that two new crustose species belong to the genus Loxospora. Both species are sterile asexually reproducing crustose lichens from the Mid-Atlantic Coastal Plain of eastern North America, and are chemically similar to $L$. lecanoriformis in producing 2-0-methylperlatolic acid. Loxosopora assateaguensis is a sorediate species that is described from a single locality on Assateague Island in Maryland. Loxospora confusa is a granulose-isidiate species that is widespread in the Mid-Atlantic with a disjunct population in the Joccassee Gorges of the southern Appalachian Mountains.
\end{abstract}

Key Words: Ropalospora; Haematomma; Lecanoromycetidae; maritime forest.

\section{INTRODUCTION}

The Coastal Plain of eastern North America comprises the Atlantic coastline and associated lowland ecosystems from southeastern Maine to the United States/Mexican border in Texas (CEC 1997; Omernik 1995). This extensive region has been subdivided based on differences across a suite of biotic and abiotic factors (US EPA 2002). Among these subdivisions, the region in which natural habitats have been, and continue to be, most impacted and threatened by anthropogenic change is the MidAtlantic Coastal Plain (hereafter abbreviated MACP) (Drummond and Loveland 2010; Ricketts et al. 1999). The MACP encompasses an area approximately the size of Alabama ( $\sim 51,600$ square mi or $\sim 133,600$ square $\mathrm{km}$; Ricketts et al. 1999) that extends along the Atlantic Coast from southern New Jersey to northern Florida (Loveland and Acevedo 2000; U.S. EPA 2002). Despite being topographically homogeneous, the region hosts high habitat and community heterogeneity (Christensen 1988) and thus a remarkable diversity of natural communities. These communities collectively host a highly diverse biota including many endemic and disjunct species, placing the MACP among the most biologically significant ecoregions in North America (Hall and Schafale 1999).

Unfortunately, after more than four centuries of intensive human habitation much of the natural landscape of the MACP has been altered (Watts 1999). Although lichens are a diverse and conspicuous component of the biota of the MACP, the region has received relatively little attention from lichenologists and has never been the subject of intensive floristic inventory efforts. To remedy this lack of data the author and his colleagues began a large scale biodiversity inventory of the lichens growing in the MACP in 2012.

One of the primary goals of this project is to document and describe the diversity of sterile crustose lichens that reproduce through the dispersal of lichenized diaspores. These fungi are considered to be among the most taxonomically difficult and understudied lichens (Kantvilas and Lumbsch 2010; Hodkinson and Lendemer 2012). This is remarkable because sterile crustose lichens represent a significant proportion of lichen biodiversity and many species are conspicuous, common, or widespread (Arup and Grube 1999; Harris and Lendemer 2010; Lendemer 2011).

One of the factors hindering taxonomic description of sterile crusts is the absence of sexual fruiting bodies, so molecular data are frequently needed to place otherwise phenotypically recognizable taxa into a higher level taxonomic framework. Following the approach outlined by Hodkinson and Lendemer (2012), molecular data are here used to establish the phylogenetic placement and taxonomic circumscription of two species of sterile crustose lichens encountered during inventory efforts in the MACP. Although phenotypically distinctive, formal description of these taxa was precluded by the fact that they could not unequivocally be assigned to a specific genus or family using only non-molecular characters. The species are shown to belong to a clade within the genus Loxospora that includes the recently described species $L$. lecanoriformis Lumbsch, A.W. Archer and Elix (Lumbsch et al. 2008). Based on morphological and chemical differences between the taxa in question and those already assigned to Loxospora, they are described as new to science under the names $L$. assateaguensis and $L$. confusa.

\section{MATERIALS AND METHODS}

Morphological and Chemical Methods

This study is based on material deposited in the herbarium of The New York Botanical Garden (NY) as 
well as material loaned from LG. The morphology of all specimens was studied using standard light and compound microscopy as outlined by Lendemer (2011). Selected specimens were studied with Scanning Electron Microscopy (SEM) following the methods of Lendemer (2011a).

Spot tests were performed following Brodo et al. (2001) and Thin Layer Chromatography (TLC) was performed in solvents $\mathrm{A}$ and $\mathrm{C}$ following Culberson and Kristinsson (1970). Samples of Mycoblastus caesius (Coppins \& P. James) Coppins \& Tønsberg (Lendemer 33268, NY) and Ropalospora viridis (Tønsberg) Tønsberg (Lendemer 33975, NY) were used as standards for perlatolic acid. A sample of Pertusaria globularis (Ach.) Tuck. (Tripp 1077, NY) was used as a standard for 2-0methylperlatolic acid.

\section{Molecular Phylogenetic Methods}

Sequence generation.-Sample preparation, DNA extraction, PCR amplification of nrITS and mtSSU, and sequence assembly follow the methods outlined in detailed by Hodkinson and Lendemer (2012).

Alignment assembly, taxon sampling, and molecular phylogenetic analyses. - Based on the bit score results of BLASTn searches all newly generated mtSSU sequences were considered to have a close affinity to Loxospora lecanoriformis, which was described by Lumbsch et al. (2007). In order to evaluate the affinities of the newly generated sequences indicted by BLASTn, they were included in an mtSSU dataset that was assembled using the taxon sampling of Lumbsch et al. (2007) except that the outgroup taxa Cladosporium sp. and Myriangium duriaei were excluded. Instead members of the Candelariaceae were selected as the outgroup following Lumbsch et al. (2008) and Hofstetter et al. (2007).

The dataset was aligned using the MAFFT online interface and manual adjustments were made in Mesquite 2.0 (Maddison and Maddison 2009). Ambiguously aligned regions were defined as part of an exclusion set. The alignment was then prepared for a maximum likelihood (ML) analysis by manually deleting the excluded regions, transforming the terminal gaps (-) to missing (?), and transforming uncertainties/polymorphisms to missing (?). The alignment was then exported as a PHYLLIP formatted file using Mesquite and a rapid ML topology search and bootstrap analysis with 500 replicates was performed using model GTRGAMMA in RAxML 7.2.6 (Windows executable). The results of the ML analyses were visualized in FigTree 1.3.1.

Based on the results of the above analyses (see Appendix 1 and results section below) the dataset used above was pruned to include the following early diverging members of the Lecanoromycetes as per Miadlikowska et al. (2006) and Hofstetter et al.
(2007): members of the Acarosporales, Candelariales, Sarrameanales (fide Hodkinson and Lendemer 2011), and Umbilicariales. Taxon sampling was then expanded by 1) adding the mtSSU sequences of Acarosporales, Candelariales used by Lumbsch et al. (2008), 2) adding all available mtSSU sequences of Loxospora from GenBank, and 3) increasing representation of crustose taxa within the Umbilicariales to include all available GenBank sequences of Fuscidea, Hypocenomyce, Maronea, and Ropalospora. The dataset was then realigned and prepared for another ML analysis following the methods outlined above.

In addition to analyses with ML the same alignment was then analyzed with maximum parsimony (MP) and Bayesian inference (BI). MP analyses were conducted using PAUP* $4.0 \mathrm{~b} 10$ on a version of the dataset with ambiguously aligned regions and constant sites excluded. An initial search was made with 1,000 randomaddition-sequence (RAS) replicates and tree bisection reconnection (TBR) branch swapping. The MULTREES option was in effect and zero-length branches were collapsed. All equally most parsimonious trees were saved with branch lengths, and a strict consensus tree was computed for reference. In this analysis the best tree island was hit in $75 \%$ of the replicates, and 24 equally most parsimonious trees were recovered (all equally most parsimonious trees were topologically equivalent). Branch support for MP trees was estimated with bootstrap analyses (Felsentein 1985) by performing 1,000 bootstrap replicates with five RAS per bootstrap replicate, with all other settings as above. The results of these analyses were visualized in PAUP and the trees exported as PICT files.

For BI analyses MrModeltest (Nylander 2004) was used to select a proper model of nucleotide substitution. Using the Akaike Information Criterion (AIC; Akaike 1973), GTR+I+G was selected. BI was performed using MrBayes 3.1.2 (Huelsenbeck and Ronquest 2001) and a NEXUS formatted version of the alignment. A MrBayes block was produced through the online automated from found at the Santos Lab website (http://131.204.120.103/ srsantos/mrbayes_form/index.html). The model settings produced by MrModeltest were pasted directly into the MrBayes block. The Markov chain Monte Carlo parameters consisted of 10,000,000 generations, with four chains, and a tree sampled every 100 generations. The first 10,000 trees were discarded as burn-in and the results were summarized as a $50 \%$ majority rule consensus tree. The results of the BI analyses were visualized in FigTree 1.3.1.

In order to examine the species level relationships between the taxa in question and other members of Loxospora s.1. a dataset was assembled that included 1) all available nrITS sequences of Loxospora from GenBank, 2) nrITS sequences generated from the same 
vouchers at the mtSSU sequences discussed above, and 3) three sequences of Umbilicaria for the outgroup that were recovered as among the nearest BLASTn hits (within the top 20 hits arranged by bit score) for the newly generated sequences. The dataset was aligned as outlined above for the mtSSU dataset. MP, ML, and BI analyses were performed in the same manner for the mtSSU dataset except that AIC selected SYM+G as the appropriate model for implementation in BI.

The alignment files used in all analyses described above have been deposited in the Dryad Data Repository and are available as http://dx.doi.org/10.5061/ dryad.t00r3. GenBank accession numbers are as follows: isolate NY-1394 (Lendemer 31891, nrITS: KF028593, mtSSU: KF028590), isolate NY-1400 (Lendemer 37062, nrITS: KF028594, mtSSU: KF028591), and isolate NY-1408 (Lendemer 30987, nrITS: KF028595, mtSSU: KF028592).

\section{RESULTS}

Populations corresponding to two sterile asexually reproducing crustose lichens were encountered during a biodiversity inventory of the MACP. Based on their shared morphology (shiny corticate thallus, coccoid green photobiont) and chemistry (production of 2-0methylperlatolic acid) it was hypothesized that they likely represented two related species that differed in thallus morphology and diaspore production (i.e., a verruculous thallus with coarse soredia vs. a smooth thallus with granulose-isidia). Although both entities were readily identifiable, even in the field, the absence of sexual characters precluded a higher level taxonomic placement and thus prevented them from being formally described. Indeed morphological and chemical characters alone could have suggested placement in Fuscidea or Ropalospora (Umbilicariales: Umbilicariomycetidae), Loxospora s.1. (Sarrameanales: Ostropomycetidae), $M y$ coblastus (Mycoblastaceae: Lecanoromycetidae), Pertusaria DC. (Pertusariales: Ostropomycetidae) or even Lecanora (Lecanoraceae: Lecanoromycetidae).

A series of molecular phylogenetic analyses were performed on representative mtSSU sequences to resolve the higher level placement of the aforementioned entities. Initial BLASTn searches of the non-redundant nucleotide collection in GenBank indicated an affinity of the newly generated sequences to the crustose lichen Loxospora lecanoriformis. In molecular phylogenetic analyses of combined $\mathrm{mtSSU}$ and nuLSU sequence data Lumbsch et al. (2007) recovered L. lecanorioides as sister to L. ochrophaea (Tuck.) R.C. Harris in a supported clade whose inclusion within the Lecanoromycetes was also supported (note that specific support values were not indicated in that work). The position of this clade was however, unsupported with respect to lineages within the Lecanoromycetidae and Ostropomycetidae. A preliminary analysis of mtSSU sequence data using nearly the same taxon sampling as Lumbsch et al. (2007), but with members of the Candelariomycetidae selected as the outgroup, produced similar results wherein the newly generated sequences were strongly supported as members of Loxospora (see Appendix 1).

Though the placement of the newly generated sequences within Loxospora s.l. was established from the aforementioned analyses, the resolution and support outside of the clade in question was poor. As such the original mtSSU dataset was pruned to include a smaller selection of lineages, namely Loxospora and other early diverging lineages within the Lecanoromycetes based on Miadlikowska et al. (2006). Taxon sampling within those lineages was then also increased following Lumbsch et al. (2008), a study which included Loxospora, and Miadlikowska et al. (2006). The results of the molecular phylogenetic analyses of the pruned dataset are summarized in Figure 1.

These analyses not only strongly supported the inclusion of the newly generated sequences within a monophyletic Loxospora, but also recovered members of the genus in two distinct clades. Members of the clade corresponding to Loxospora s. str. (i.e., L. cismonica, $L$. elatina (Ach.) A. Massal., and L. ochrophaea) all produce thamnolic acid, have acicular septate ascospores that are spirally arranged within the ascus, and occur in temperate or boreal regions of the northern hemisphere (Staiger and Kalb 1995). Conversely members Loxospora s.1. (i.e., L. lecanoriformis and the taxa newly described here) produce 2-0-methylperlatolic acid and occur in subtropical regions of the northern and southern hemispheres. Ascospores are only known in Loxospora s.1. from L. lecanoriformis, and while elongate-ellipsoid and simple, they are spirally arranged within the ascus in a peculiar manner that resembles that of the ascospores of Loxospora s. str. (Lumbsch et al. 2008). These differences were noted by Lumbsch et al. (2008) when describing L. lecanoriformis however they refrained from recognizing the species in a separate genus. While the increased sampling presented here points to the potential need to recognize two genera within Loxospora, this should not be done until the additional species with thamnolic acid described from Australasia are also studied (e.g., Kantvilas 2000)

Following the analyses of mtSSU sequence data an additional set of nrITS sequences were analyzed to examine relationships within Loxospora, and between the two putative new species. The results of these analyses, which are summarized in Figure 2, recovered two clades within Loxospora corresponding to those that were also recovered in the mtSSU analyses. Unfortunately, nrITS sequences were unavailable for $L$. lecanoriformis. Nonetheless, the sequences representing 


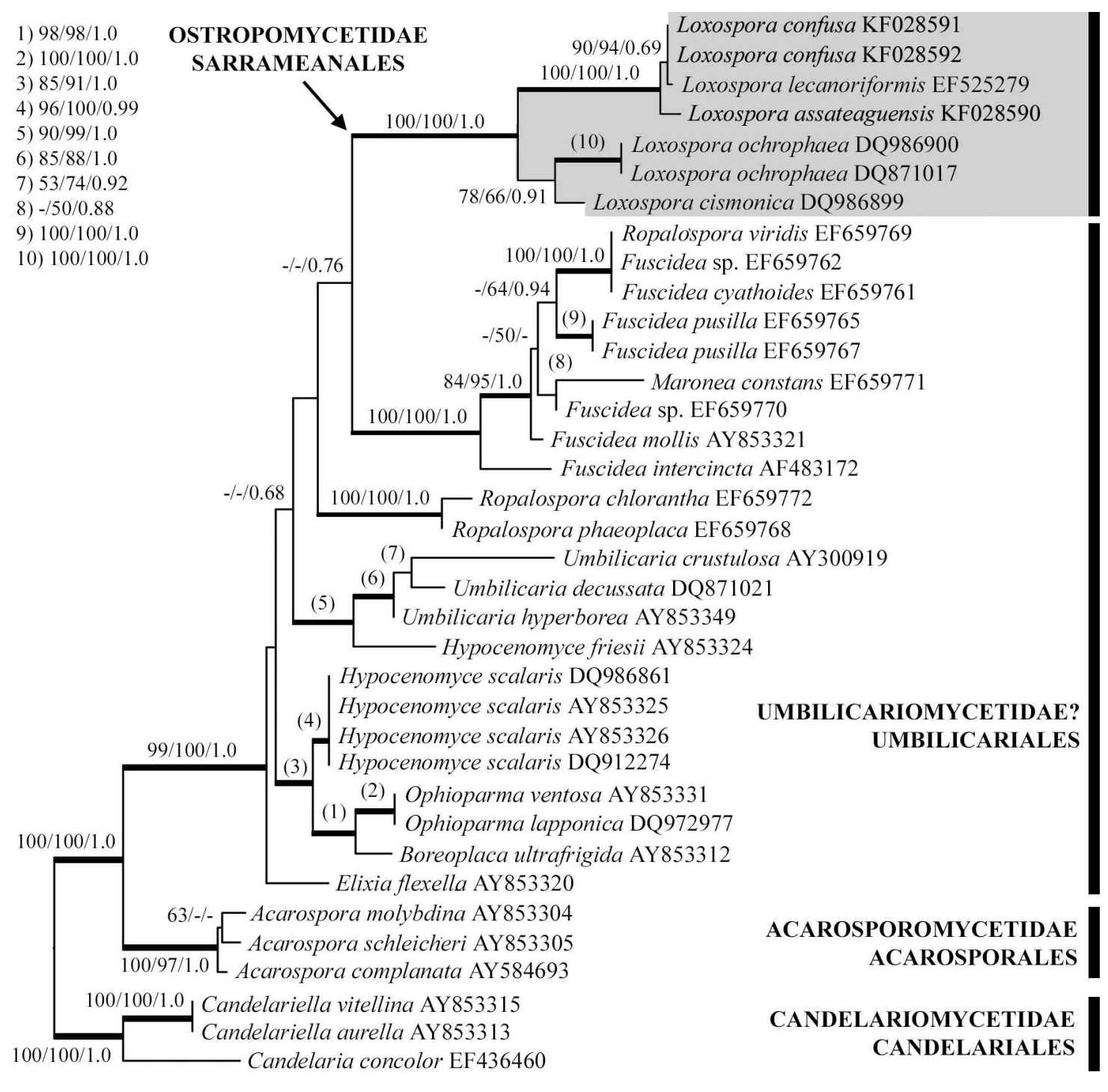

0.03 substitutions/site

FIG. 1. Phylogeny of early diverging lineages within the Lecanoromycetes illustrating the placement of the newly generated sequences within Loxospora (shaded clade), inferred from mtSSU sequence data and displayed as the most likely tree with Candelariomycetidae selected as the outgroup following Hofstetter et al. (2007). Support was evaluated using maximum parsimony (MP) and maximum likelihood (ML) bootstrap proportions (BP) and Bayesian posterior probabilities (B-PP). Support values $>50 \%$ are displayed at each note in the following format: MP-BP/ ML-BP/B-PP. Branches with MP-BP and ML-BP support $>70 \%$ as well as B-PP support $<95 \%$ are thickened.

the two putative species were strongly supported as distinct, with the two sequences of $L$. confusa forming a strongly supported clade (MP/ML/BI: 98/100/1.0) that was strongly supported (MP/ML/BI: 100/100/1.0) as sister to the lone sequence of $L$. assateaguensis. Within Loxospora s. str. the three sequences of $L$. elatina were recovered in a clade that received variable support (MP/ ML/BI: 79/97/0.71) and was strongly supported (MP/ ML/BI: 99/100/1.0) as sister to lone sequence of $L$. ochrophaea. This clade was also recovered in a strongly supported (MP/ML/BI: 100/100/1.0) sister relationship with $L$. cismonica. Considering the similarities in apothecial morphology between $L$. ochrophaea, which is esorediate, and L. elatina which is sorediate, it would be interesting for a future study to explore whether the taxa represent a true "species pair" (Poelt 1970).

\section{TAXONOMIC SECTION}

Loxospora assateaguensis Lendemer sp. nov.

Mycobank \#804491

(Fig. 3A, C and E)

TYPE: U.S.A. MARYLAND. WORCESTER CO.: Assateague Island National Seashore, Assateague Island, km. 29.1, Green Run/Jackson's Hunting Lodge, E shore of Green Run Bay, elev. $1 \mathrm{ft}$, maritime forest of Pinus and mixed hardwoods (Persea, Nyssa, Ilex, 


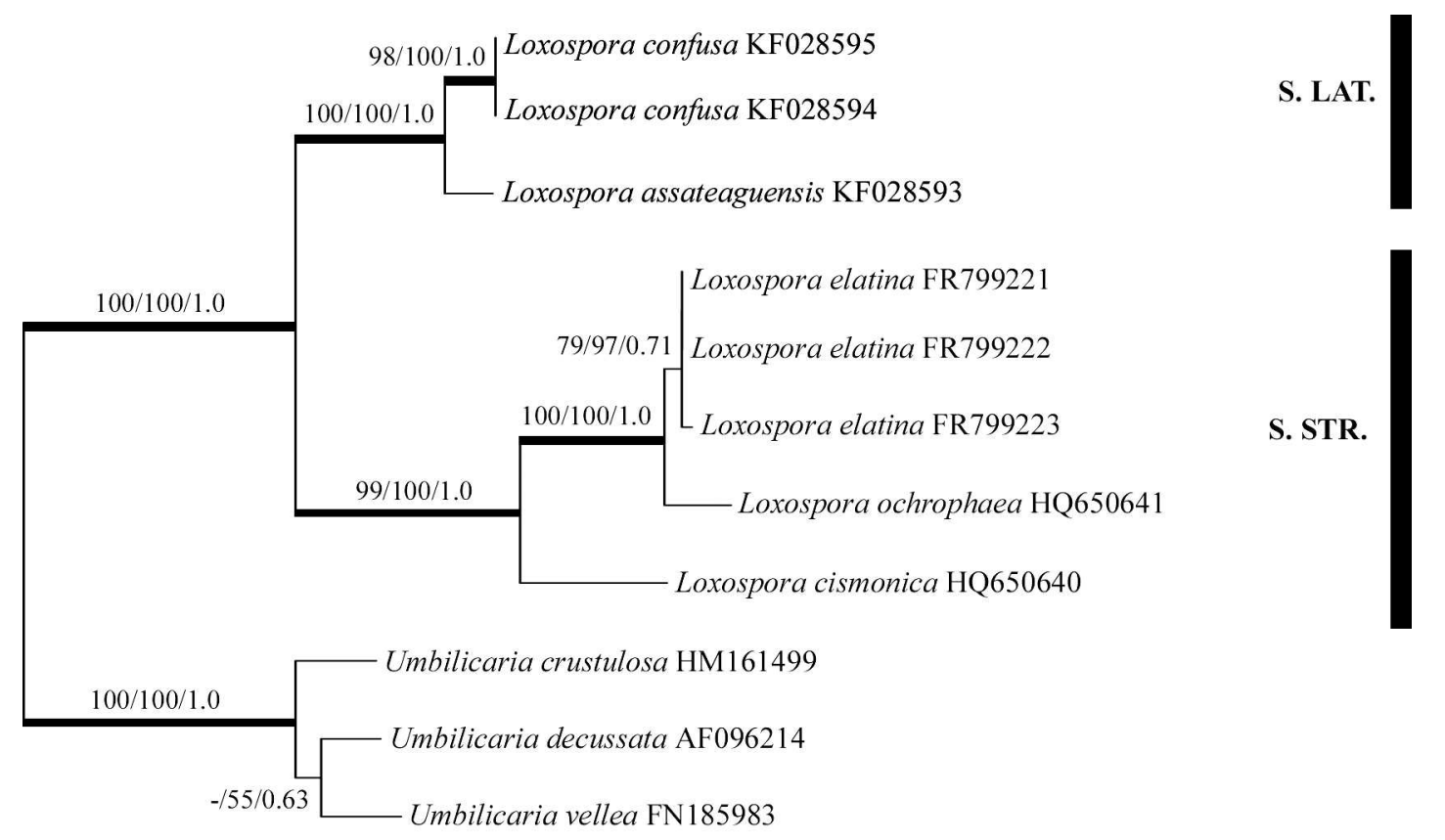

0.03 substitutions/site

FIG. 2. Phylogeny of Loxospora illustrating relationships within the genus inferred from nrITS sequence data and displayed as the most likely tree with three sequences of Umbilicaria selected as the outgroup (note Umbilicaria was selected because only one nrITS sequence of Fuscidea and no sequences of Ropalospora were available in GenBank). Support was evaluated using maximum parsimony (MP) and maximum likelihood (ML) bootstrap proportions (BP) and Bayesian posterior probabilities (B-PP). Support values $>50 \%$ are displayed at each note in the following format: MP-BP/ML-BP/B-PP. Branches with MP-BP and ML-BP support $>70 \%$ as well as B-PP support $<95 \%$ are thickened. The two clades within Loxospora corresponding to the genus in a strict sense (s. str.) and broad sense (s. lat.) are indicated with labels and black bars on the right.

Diospyros, Amelanchier and Baccharis), 26.iv.2012, on Ilex opaca base, J.C. Lendemer et al. 31891 (NY!, holotype).

Diagnosis.-A distinctive species of Virginian Barrier Island maritime forests differing from Loxospora confusa and $L$ lecanoriformis in having a thick, verruculose thallus and producing coarse soredia from pustular soralia.

Description.-Thallus crustose, continuous, sorediate, beginning as small circular colonies overlap, expand, and eventually merge to form an extensive colony; prothallus white, not zoned, not fibrous; upper surface corticate, shiny, light whitish-blue in color, smooth near the margins but quickly becoming uneven and verruculose towards the center; hyphae hyaline, septate, branching, 2-4 $\mu \mathrm{m}$ wide; cortex a thin covering of prosoplectenchymatous, gelatinized hyphae, 10-20 $\mu \mathrm{m}$ thick; medulla white, I-, 250-300 $\mu \mathrm{m}$ thick, comprising an irregularly arranged textura intricata embedding a layer of photobiont cells $\sim 30-50 \mu \mathrm{m}$ thick subtended by irregularly shaped clusters of calcium oxalate crystals; soralia erumpent, circular, without a discrete rim; soredia coarse, $30-70 \mu \mathrm{m}$ in diameter. Apothecia and pycnidia not observed. Photobiont coccoid, cells 5$10 \mu \mathrm{m}$ in diameter.

Chemistry.-2-0-methylperlatolic acid. Spot tests: K-, C-, KC-, P-, UV+ blue-white.
Etymology.-The epithet "assateaguensis" refers to the location of the type locality on Assateague Island in Assateague Island National Seashore.

Ecology and distribution.-The new species is known only from the type locality, an old growth maritime forest comprised of mixed hardwoods (Diospyros, Ilex, Magnolia virginiana, Quercus) that also hosts the northernmost known populations of Persea. The type locality comprises the oldest forest remaining on Assateague Island, dating to at least 1880 , and is amongst the oldest forests remaining on the Delmarva Peninsula (Maryland DNR undated). It is thus likely that the site is a unique, remnant old-growth maritime forest of the Virginian Barrier Islands and Coastal Marshes Ecoregion (hereafter abbreviated VBI) of the MACP.

The uniqueness of the type locality is supported by the unusual lichen community found there, which includes tropical species such as Phaeographis haematites (Fée) Müll. Arg. The nearest known populations of $P$. haematites occur in Georgia and it is interesting to note that at Green Run the species was associated only with the genus Persea as a host. We hypothesize that $L$. assateaguensis is restricted to the VBI Ecoregion, where it was once widespread in mature maritime forest communities. The extensive alterations of these communities during the last four centuries may have resulted 


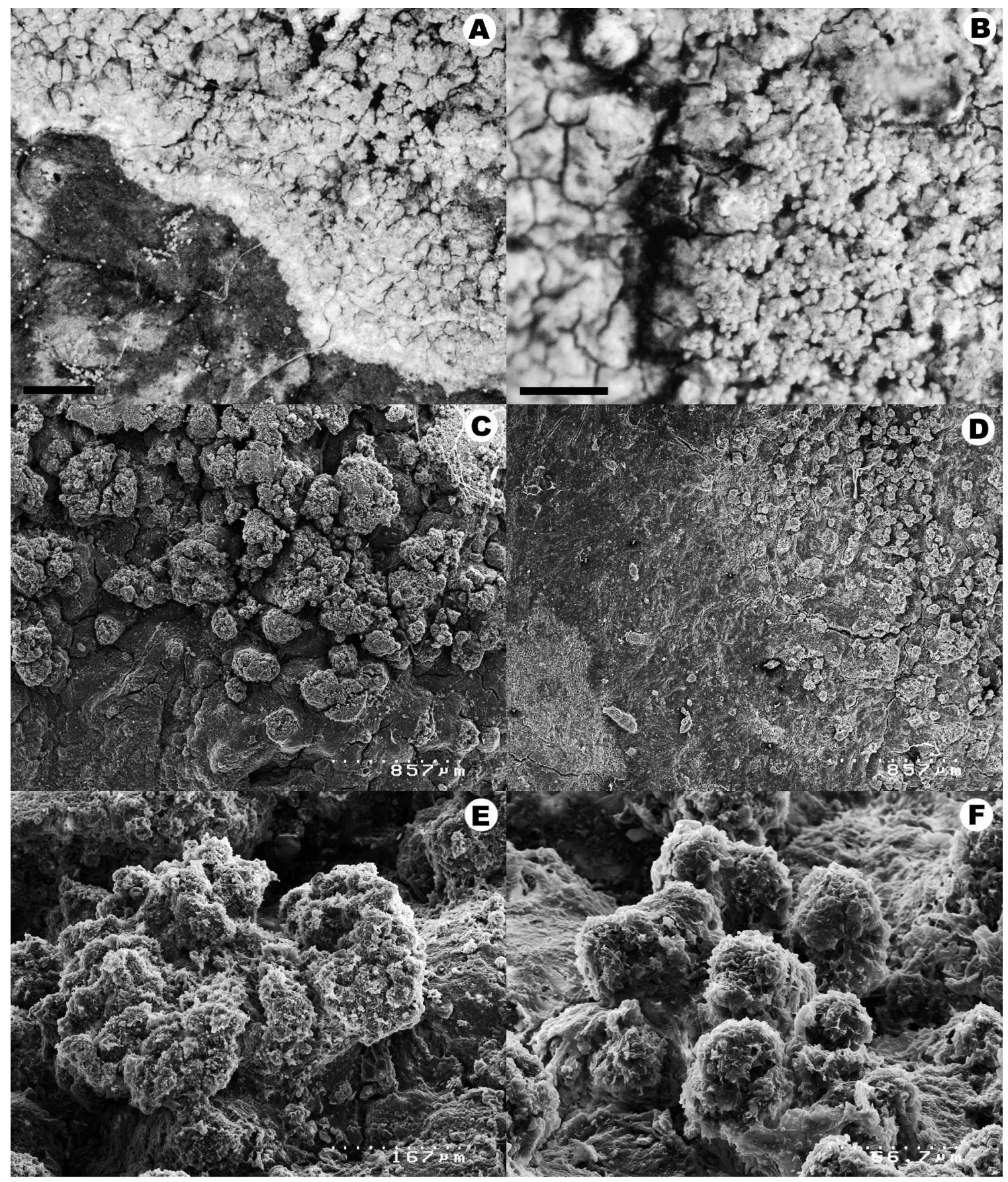

FIG. 3. Comparison of thallus and diaspore morphology in Loxospora assateaguensis (left; all from holotype) and L. confusa (right; B from Lendemer 34812, D and F from Lendemer 20091). A-B, gross morphology of the thallus (scales 1.0 and $0.5 \mathrm{~mm}$ respectively). C-D, scanning electronic micrographs (SEMs) of the gross morphology of the thallus (scales as indicated). E-F, SEMs of the lichenized diaspores (scales as indicated).

in extirpation of the species from most of its native range. Because of the relative inaccessibility of barrier island maritime forest habitats in the VBI Ecoregion it is possible that species persists at sites not surveyed during our inventory. Surveys of these sites should be undertaken to better understand the modern distribution of the new species.
Discussion.-Based on the available molecular data Loxospora assateaguensis is most closely related to $L$. confusa, another asexually reproducing species from the Mid-Atlantic Coastal Plain that is newly described here. Both species have a distinctive shiny thallus, a coccoid photobiont and produce 2-0-methylperlatolic acid. Loxospora assateaguensis differs from $L$. confusa in 
producing coarse soredia that are borne in pustular soralia that form apically on the thalline verrucae (vs. clusters of fragile, granulose isidia). Molecular data also indicates a relationship with $L$. lecanoriformis which differs from $L$. assateaguensis in the absence of lichenized diaspores and distribution which is so far restricted to tropical and sub-tropical Australasia.

Considering chemical and morphological characters there are relatively few species in eastern North America that are similar to Loxospora assateaguensis. Phlyctis boliviensis Nyl. and Variolaria pustulata (Brodo and W.L. Culb.) Lendemer, Hodkinson and R.C. Harris are two sympatric species with blue-gray sorediate thalli that could be confused with the new taxon (Lendemer 2010). The former species differs in the production of psoromic acid rather than 2-0-methylerpatolic acid and in the fact that sterile thalli produce irregular convex areoles rather than soredia that form in soralia. The latter taxon differs in the production of thamnolic acid rather than 2-0-methylperlatolic acid and schizidia that arise from the breakdown of pustules rather than soredia the formed in soralia. Another similar species is Ropalospora viridis (Tønsberg) Tønsberg, although that species produces perlatolic acid and has a green (vs. blue-gray) thallus (Lendemer 2011). It would also be possible to confuse the new species with sorediate members of the genus Haematomma, particularly $H$. americanum $\mathrm{Kalb}$ and Staiger or $H$. guyanense Kalb and Staiger. The thallus morphology in both species is variable and extreme forms can approach $L$. assateaguensis in appearance. However, both species typically form a well-developed fibrous marginal prothallus (while L. asateguensis does not have a fibrous prothallus) and differ chemically; $H$. americanum produces atranorin and sphaerophorin and $H$. guyanense produces placodialic acids [see Brodo et al. (2008) for further details on the chemistry of Haematomma species].

\section{Loxospora confusa Lendemer sp. nov. Mycobank \#804492 \\ (Figure 3B, D and F)}

TYPE: U.S.A. NORTH CAROLINA. TYRRELL CO.: Emily \& Richardson Preyer Buckridge Coastal Reserve, NE of junction of Eastern Rd. and Grapevine Landing Rd./SR1314, $0 \mathrm{ft}$., swamp forest of Nyssa, Liquidambar, Acer and Taxodium, 11.xii.2012, on Acer, J.C. Lendemer et al. 34812 (NY!, holotype).

Diagnosis.-A distinctive member of Loxospora s.1. differing from L. assateaguensis and L. lecanoriformis in the smooth thallus and production of clusters of short, apically fragile, granulose isidia.

Description.-Thallus crustose, continuous, isidiate, beginning as small circular colonies that remain isolated and do not merge to form an extensive colony; prothallus white, not zoned, not fibrous; upper surface obscurely corticate, shiny, light whitish-blue in color, smooth; hyphae hyaline, septate, branching, 2-4 $\mu \mathrm{m}$ wide; cortex a thin covering of prosoplectenchymatous, gelatinized hyphae, 10-20 $\mu \mathrm{m}$ thick; medulla white, I-, 100-150 $\mu \mathrm{m}$ thick, comprising a irregularly arranged textura intricata embedding a layer of photobiont cells $\sim 30 \mu \mathrm{m}$ thick subtended by irregularly shaped clusters of calcium oxalate crystals; isidia arising in small dense clusters, short, simple or coralloid, often constricted at the base, noticeably fragile and often with a hollow, weakly corticate apex that is easily fragments to give the appearance of heaps of soredia or pustules, 100-200 $\mu \mathrm{m}$ tall and $\sim 50 \mu \mathrm{m}$ wide. Apothecia and pycnidia not observed. Photobiont coccoid, cells 4-7 $\mu \mathrm{m}$ in diameter.

Chemistry.-2-0-methylperlatolic acid. Spot tests: K-, $\mathrm{C}-, \mathrm{KC}-, \mathrm{P}-, \mathrm{UV}+$ blue-white.

Etymology.-The epithet "confusa" refers to the confusing nature of the lichenized diaspores which resemble soredia at a distance but are actually dense clusters of short, granulose isidia.

Ecology and distribution.-Loxospora confusa appears to be infrequent but widespread throughout the MACP of eastern North America (Fig. 4) where it occurs on the bark of hardwood trees, particularly Acer and Ilex. More rarely the species occurs on the branches of small shrubs (Lyonia) and the bark of conifers (Chamaecyparis). A single collection from the Joccassee Gorges of the southern Appalachian Mountains also appears to be referable the new species. Although the collection differs in having somewhat longer, more developed isidia, the occurrence of other subtropical lichen species in that region has been documented (Lendemer \& Tripp 2008).

Discussion.-As has been outlined above Loxospora confusa is closely related to L. assateaguensis, a species known only from Assateague Island in Maryland, USA. The new species differs from $L$. assateaguensis in producing clusters of short, granulose isidia rather than coarse soredia formed in soralia that arise from thalline verrucae. There are relatively few species of crustose lichens in eastern North America that produce isidia, and fewer still that are sympatric with the new species in the MACP. The species that most closely resembles $L$. confusa is Pertusaria globularis, an isidiate species that occurs in the Appalachian Mountains and Great Lakes Regions (Dibben 1980). That taxon differs from $L$. confusa in the production of a xanthone in addition to 20 -methylperlatolic acid, its geographic distribution, and, when fertile, in the production of apothecia in thalline warts (Dibben 1980). Protoparmelia isidiata Diederich, Aptroot \& Sérus. could also be confused the new species, but that taxon differs in having long coralloid isidia with brown tips and in the production of alectoronic acid (Lendemer \& Lumbsch 2008). Megalaria pannosa (Zahlbr.) Fryday and Lendemer is also similar to L. confusa, but occurs further south in the 


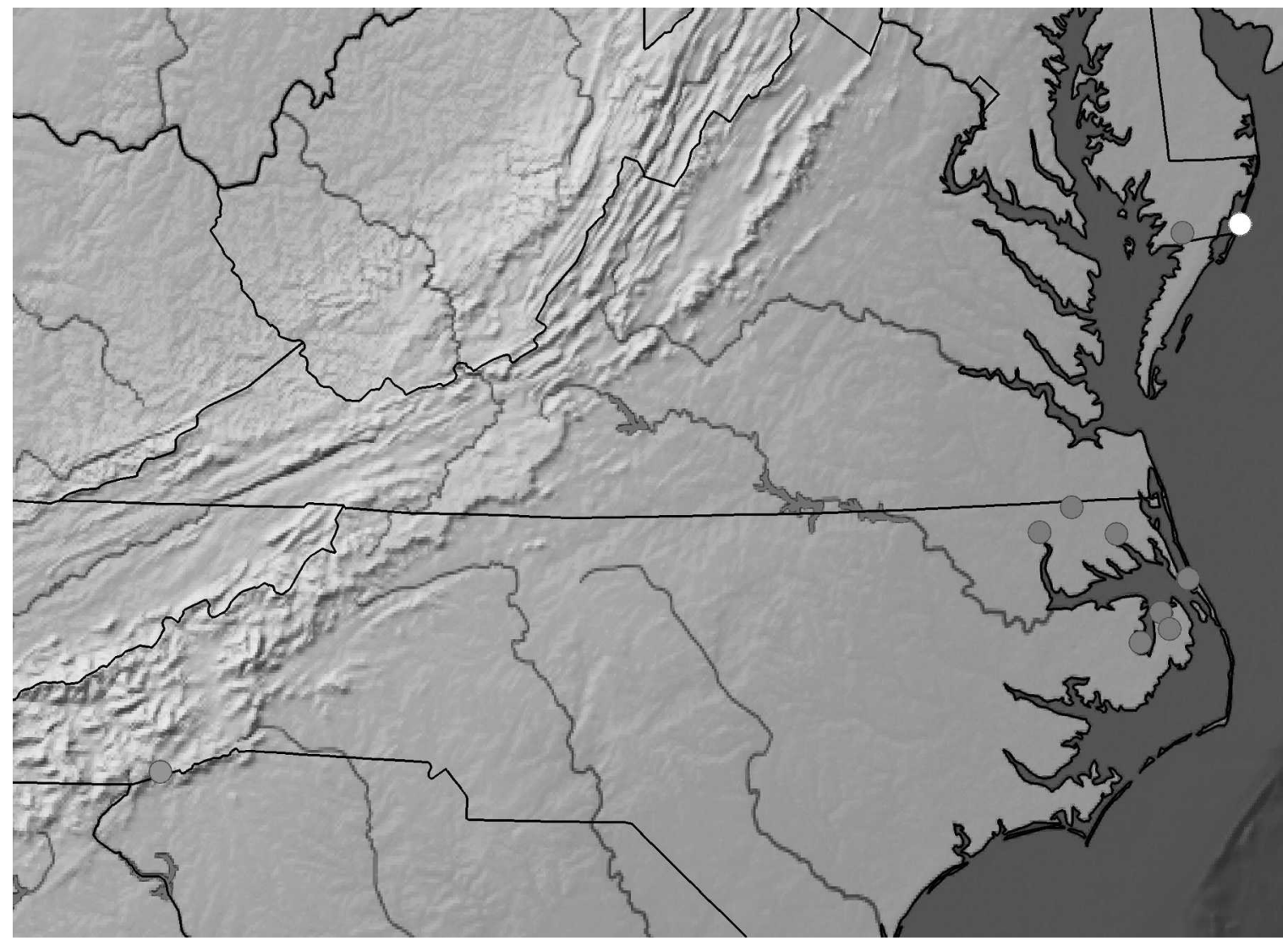

FIG. 4. Geographic distribution if Loxospora assateaguensis (white dot) and L. confusa (gray dots).

Coastal Plain and produces xanthones rather than 2-0methylperlatolic acid (Fryday and Lendemer 2010).

Considering the morphological and chemical similarities between Loxospora confusa and members of the genus Pertusaria s.l. any future study of this taxon should include Pertusaria buburana Elix \& A.W. Archer. Pertusara buburana is a sterile crustose lichen with clusters of short isidia that also produces 2-0-methylperlatolic acid (Elix et al. 1997). The species was originally described from Papua New Guinea and has subsequently been reported from Australia (Archer and Elix 2009). Unfortunately the species has not been found in a fertile state and fresh material is not available for sequencing. Thus it is not possible at present to rule out a link between $P$. buburana and the new species. Such a link is not implausible in light of geographic distribution of Protoparmelia isidiata, a species originally described from Papua New Guinea that has subsequently been found to be widespread throughout the tropics (Lendemer and Lumbsch 2008). Indeed, the holotype of P. buburana ${ }^{1}$

\footnotetext{
${ }^{1}$ Holotype of Pertusaria buburana Elix \& Archer: PAPUA NEW GUINEA. MADANG PROV.: Burbura [sic, published as "Bubura"] logging site, c. $30 \mathrm{~km}$ NNW of Madang, c. $13 \mathrm{~km}$ along road from the coast, elev. $70 \mathrm{~m}$, virgin rainforest on low hills, 28.vii.1992, [on bark], P. Diederich et al. 11929 (LG!, holotype).
}

closely resembles an aberrant collection of Loxospora confusa from North Carolina (Lendemer 34259, NY) in which although the isidia are hollow, they are robust rather than fragile, and do not fragment apically.

Additional specimens examined.-U.S.A. MARYLAND. WORCESTER CO.: Pocomoke State Forest, Hickory Point Swamp, E of access road, $0.5 \mathrm{mi} \mathrm{N}$ of jct w/Hickory Point Rd., 15.xi.2012, on Ilex opaca, J.C. Lendemer et al. 34020 (NY). NORTH CAROLINA. CAMDEN CO.: North River Game Land, $\mathrm{S}$ of Shipyard Rd. 0.6 mi SW of intersection w/NC343, $0.4 \mathrm{mi}$ E of Pasquotank River, 12.iv.2012, on Acer, J.C. Lendemer et al. 30762 (NY); Dismal Swamp State Park, S side of Corapeake Ditch, between Western Boundary Ditch and Myrtle Ditch, 10.xiii.2009, on Acer, J.C. Lendemer 20091 \& S. Williams (NY). DARE CO.: Kitty Hawk Woods Coastal Reserve, $0.5 \mathrm{mi}$ W of The Woods Rd., $0.6 \mathrm{mi} \mathrm{N}$ of Twiford Rd., 14.iv.2012, on Acer, J.C. Lendemer et al. 31097 (NY); Alligator River National Wildlife Refuge, $0.4 \mathrm{mi} \mathrm{N}$ of bridge at Milltail Creek, 9.xii.2012, on Acer, J.C. Lendemer et al. 34242 (NY), on Lyonia, J.C. Lendemer et al. 34249 (NY), on Chamaecyparis, J.C. Lendemer et al. 34259 (NY); Alligator River National Wildlife Refuge, Brier Hall Rd. $1.6 \mathrm{mi} \mathrm{N}$ of jct w/US64, 8.xii.2012, on Acer, J.C. Lendemer et al. 34080 (NY). GATES CO.: Great Dismal Swamp 
National Wildlife Refuge, W side of Sherrill Ditch, $1.7 \mathrm{mi} \mathrm{S}$ of intersection w/Corapeake Ditch, 30.iv.2012, on Acer, J.C. Lendemer et al. 30987 (NY); Chowan Swamp Game Land, E side of New Ferry Rd., $1.3 \mathrm{mi} \mathrm{S}$ of jct w/NC137 in Gatesville, $2.1 \mathrm{mi} \mathrm{N}$ of the $\mathrm{N}$ shore of Chowan River, 12.iv.2012, on Ilex opaca, J.C. Lendemer et al. $30814(\mathrm{NY})$. TRANSYLVANIA CO.: Gorges State Park, along road between Bearwallow River and Toxaway River, 12.viii.2005, on Acer, J.C. Lendemer $4861 \&$ E. Tripp (NY). TYRRELL CO.: Pocosin Lakes National Wildlife Refuge, Frying Pan Boating Access, 10.xii.2012, on Acer, R.C. Harris 58387 (NY).

Acknowledgments: All aspects of this study were supported by NSF Award DEB-1145511 to the author (PI) and R.C. Harris (co-PI). Jessica Allen is thanked helpful discussion, particularly with regard to the taxon sampling of molecular datasets. The staff of Assateague Island National Seashore is thanked for facilitating our fieldwork (carried out under permit ASIS-2012-SCI-0006) on the island and also for providing useful information pertaining to the type locality of Loxospora assateaguensis. The following are also thanked for providing permission to conduct fieldwork in management units where material used for this study was collected: Alligator River National Wildlife Refuge, Great Dismal Swamp National Wildlife Refuge, Maryland Department of Natural Resources (Pocomoke State Forest), North Carolina Wildlife (North River Game Land), North Carolina Estuarine Research Reserve (Kitty Hawk Woods CR), and North Carolina Parks and Recreation (Chowan Swamp NA, Dismal Swamp SP, Gorges SP).

\section{LITERATURE CITED}

AKAIKE, H. 1973. Information theory and an extension of the maximum likelihood principle. Pp. 267-281 in B. N. Petrov and F. Csaki (eds.), Second international symposium on information theory, Springer-Verlag, Berlin.

ARCHER, A. W., AND J. A. ELIX. 2009. New species and new reports in the lichen genus Pertusaria (Ascomycota: Pertusariaceae) from Australasia. Nova Hedwigia 88(1-2):1-10.

ARUP, U., AND GRUBE, M. 1999. Where does Lecanora demissa (Ascomycota, Lecanorales) belong? Lichenologist 31(5):419430.

BRODO, I. M., W. L. CULBERSON, AND C. F. CULBERSON. 2008. Haematomma (Lecanoraceae) in North and Central America, including the West Indies. Bryologist 111(3):363-423.

CEC (COMMISSION FOR ENVIRONMENTAL COOPERATION). 1997. Ecological regions of North America - toward a common perspective: Montreal, Quebec, Comm. Environ. Coop. $71 \mathrm{p}$.

CHRISTENSEN, N. L. 1988. Vegetation of the southeastern Coastal Plain. Pp. 17-363 in M. G. Barbour and W. D. Billings (eds.), North American Terrestrial Vegetation. Cambridge University Press, Cambridge, United Kingdom.

CULBERSON, C. F., AND H. KRISTINSSON. 1970. A standardized method for the identification of lichen products. J. Chromatogr. 46:85-93.
DIBBEN, M. J. 1980. The Chemosystematics of the Lichen Genus Pertusaria in North America North of Mexico. Publications in Biology and Geology No. 5, Milwaukee Public Mus. Press, Milwaukee. 162 p.

DRUMMOND, M. A., AND T. R. LOVELAND. 2010. Land-use Pressure and a Transition to Forest-cover Loss in the Eastern United States. Bioscience 60(4):286-298.

ELIX, J. A., A. APTROOT, AND A. W. ARCHER. 1997. The lichen genus Pertusaria (lichenised Ascomycotina) in Papua New Guinea and Australia: twelve new species and thirteen new reports. Mycotaxon 64:17-35.

FELSENSTEIN, J. 1985. Confidence limits on phylogenies: an approach using the bootstrap. Evolution 39:783-791.

FRYDAY, A. M., AND J. C. LENDEMER. 2010. Reassessment of the genus Catillochroma (lichenized Ascomycota, Ramalinaceae). Lichenologist 42(5):587-600.

HALL, S. P., AND M. P. SCHAFALE. 1999. Conservation Assessment of the southeast Coastal Plain of North Carolina, using siteoriented and landscape-oriented analyses. Raleigh, NC. 261 p.

HARRIS, R. C., AND J. C LENDEMER. 2010. A review of Lecania croatica (syn. Catillaria croatica) in North America. Opuscula Philolichenum 8:41-49.

HODKINSON, B. P., AND J. C. LENDEMER. 2012. Phylogeny and taxonomy of an enigmatic sterile lichen. Syst. Bot. 37(4):835844.

HODKINSON, B. P., AND J. C. LENDEMER. 2011. The orders of Ostropomycetidae (Lecanoromycetes, Ascomycota): Recognition of Sarrameanales and Trapeliales with a request to retain Pertusariales over Agyriales. Phytologia 93(3):407-412.

HOFSTETTER, V., J. MIADLIKOWSKA, F. KAUFF, AND F. LUTZONI. 2007. Phylogenetic comparison of protein-coding versus ribosomal RNA-coding sequence data: a case study of the Lecanoromycetes (Ascomycota). Mol. Phylogenet. and Evol. 44:412-426.

HUELSENBECK, J. P., AND F. RONQUIST. 2001. MRBAYES: Bayesian inference of phylogenetic trees. Bioinformatics 17:754-755.

KANTVILAS, G. 2000. Additions from the Southern Hemisphere to the lichen genus Loxospora. Herzogia 14:35-38.

KANTVILAS, G., AND H. T. LUMBSCH. 2010. A new species and new record of Australian Scoliciosporum. Australasian Lichenology 66:16-23.

LENDEMER, J. C. 2010. Preliminary Keys to the Typically Sterile Crustose Lichens in North America. Published by the author, New York. 34 pp. 32 color plates.

LENDEMER, J. C. 2011. A review of the morphologically similar species Fuscidea pusilla and Ropalospora viridis in eastern North America. Opuscula Philolichenum 9:11-20.

LENDEMER, J. C. 2011a. A standardized morphological terminology and descriptive scheme for Lepraria (Stereocaulaceae). The Lichenologist 43(5):379-399.

LENDEMER, J. C., AND H. T. LUMBSCH. 2008. Protoparmelia capitata sp. nov., and P. isidiata Diederich, Aptroot \& Sérus., two species of Protoparmelia (Lecanorales, Ascomycota) from south-eastern North America. Lichenologist 40(4):329-336.

LENDEMER, J. C., AND E. A. TRIPP. 2008. Contributions to the lichen flora of North Carolina: a preliminary checklist of the lichens of Gorges State Park. - Bryologist 111(1):57-67.

LOVELAND, T. R., AND W. ACEVEDO. 2000. Land Cover Change in the Eastern United States. United States Geological Survey, Land Cover Trends Project. Website: http://landcovertrends. usgs.gov/east/regionalSummary.html (accessed 10 March 2010).

LUMBSCH, H. T., A. W. ARCHER, AND J. A. ELIX. 2007. A new species of Loxospora (lichenized Ascomycota: Sarrameanaceae) from Australia. Lichenologist 39(6):509-517. 
LUMBSCH, H. T., M. P. NELSEN, AND R. LÜCKING. 2008. The phylogenetic position of Haematommataceae (Lecanorales, Ascomycota), with notes on secondary chemistry and species delimitation. Nova Hedwigia 86(1-2):105-114.

MADDISON, W. P., AND D. R. MADDISON. 2009. Mesquite: a modular system for evolutionary analysis. Version 2.72. http:// mesquiteproject.org.

MARYLAND DEPARTMENT OF NATURAL RESOURCES. undate. Green Run Woods, Worcester Co. Maryland Natural Areas Guide 2 pp. [accessible via: http://dnr.state.md.us/wildlife/ Publiclands/Natural_Areas/pdfs/GreenRunWoods.pdf]

MIADLIKOWSKA, J., F. KAUFF, V. HOFSTETTER, E. FRAKER, M. GRUBE, J. HAFELLNER, V. REEB, B. P. HODKINSON, M. KUKWA, R. LÜCKING, G. HESTMARK, M. G. OTALORA, A. RAUHUT, B. BÜDEL, C. SCHEIDEGGER, E. TIMDAL, S. STENROOS, I. M. BRODO, G. B. PERLMUTTER, D. ERTZ, P. DIEDERICH, J. C. LENDEMER, P. F. MAY, C. SCHOCH, A. E. ARNOLD, C. GUEIDAN, E. TRIPP, R. YAHR, C. ROBERTSON, AND F. LUTZONI. 2006. New insights into classification and evolution of the Lecanoromycetes (Pezizomycotina, Ascomycota) from phylogenetic analyses of three ribosomal RNA- and two protein-coding genes. Mycologia 98(6):1088-1103.
NYLANDER, J. A. A. 2004. MrModeltest v2. Program distributed by the author. Evolutionary Biology Centre, Uppsala, Sweden.

OMERNIK, J. M. 1995. Ecoregions: A spatial framework for environmental management. Pp. 49-62 in W. S. Davis and T. P. Simon (eds.), Biological Assessment and Criteria: Tools for Water Resource Planning and Decision Making. Lewis Publishers, Boca Raton, FL.

POELT, J. 1970. Das Konzept der Artenpaare bei den Flechten. Vortrage aus dem Gesamtgebiet der Botanik, N.F. [Deutsch. Bot. Ges.] 4:187-198.

RICKETTS, T. H., E. DINERSTEIN, D. M. OLSON, AND C. J. LOUCKS. 1999. Terrestrial ecoregions of North America: a conservation assessment. Washington, D.C., Island Press. 485 p.

STAIGER, B., AND K. KALB. 1995. Haematomma-studien. I. Die Flechtengattung Haematomma. Bibliotheca Lichenologica, 59:1-198.

U.S. ENVIRONMENTAL PROTECTION AGENCY. 2002. Level III ecoregions of the continental United States (revision of Omernik, 1987): Corvallis, Oregon, U.S. Environmental Protection Agency-National Health and Environmental Effects Research Laboratory, Map M-1, various scales.

WATTS, B. D. 1999. Partners in flight bird conservation plan for the Mid-Atlantic Coastal Plain (Physiographic Area 44) Version 1.0. American Bird Conservancy, The Plains, VA. 78 p. 
Lendemer: New Lichens From Mid-Atlantic

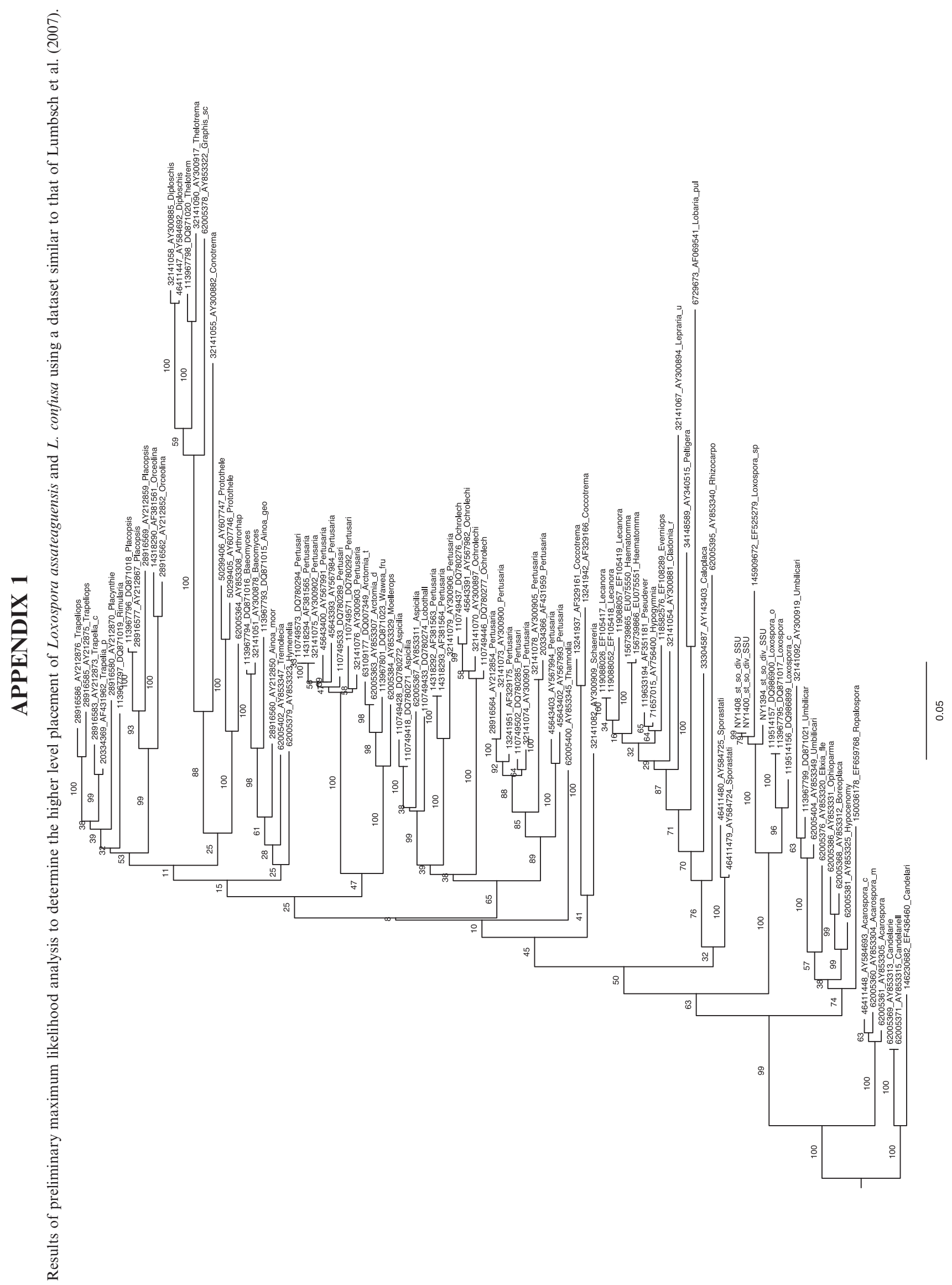

